\title{
Aphid Transmission Alters the Genomic and Defective RNA Populations of Citrus tristeza virus Isolates
}

\author{
M. R. Albiach-Martí, J. Guerri, A. Hermoso de Mendoza, F. Laigret, J. F. Ballester-Olmos, and P. Moreno
}

First, second, third, fifth, and sixth authors: Instituto Valenciano de Investigaciones Agrarias (IVIA), Cra. Moncada-Náquera Km 4.5, 46113Moncada, Valencia, Spain; fourth author: Laboratoire Cellulaire et Moléculaire, INRA, Domaine de la Grand Ferrade, BP 81, 33883Villenave d'Ornon, France.

Accepted for publication 14 October 1999.

\begin{abstract}
Albiach-Martí, M. R., Guerri, J., Hermoso de Mendoza, A., Laigret, F., Ballester-Olmos, J. F., and Moreno, P. 2000. Aphid transmission alters the genomic and defective RNA populations of Citrus tristeza virus isolates. Phytopathology 90:134-138.

A total of 14 Spanish isolates of Citrus tristeza virus (CTV) and 1 isolate from Japan were transmitted by Aphis gossypii, and the subisolates obtained were compared with the source isolates for symptom expression and double-stranded RNA (dsRNA) pattern. Of the 14 Spanish isolates, 9 showed altered dsRNA patterns after aphid transmission but only minor variations in the intensity of symptoms induced on Mexican lime. Northern

showed that the dsRNA bands that could be used to discriminate between the dsRNA pattern of the source and the aphid-transmitted isolates were the replicative forms of defective RNAs (D-RNAs). Conversely, the Japanese isolate and two subisolates obtained from it by aphid transmission had the same dsRNA pattern, but one of the subisolates induced milder symptoms in several hosts. Dot-blot hybridization with cDNA probes representing several regions of the gRNA showed that most of the aphidtransmitted isolates differed from the corresponding source isolate by their hybridization pattern. Our results indicate that aphid transmission often sorts the populations of gRNA variants and D-RNAs present in CTV isolates.
\end{abstract} blot hybridization with complementary DNA (cDNA) probes corresponding to both the $5^{\prime}$ and the $3^{\prime}$ termini of the CTV genomic RNA (gRNA)
Additional keywords: graft-inoculation.
Citrus tristeza virus (CTV), a member of the genus Closterovirus, is the causal agent of one of the most destructive diseases of citrus (6). In Spain, CTV was detected during the late 1950s and since then has caused the death of $\approx 30$ million citrus trees grafted on sour orange (Citrus aurantium L.) rootstock. The use of buds of uncontrolled origin for topworking trees to new citrus cultivars and the presence of three vector species (Aphis gossypii Glover, A. spiraecola Patch, and Toxoptera aurantii (Boyer de Fonscolombe)) (14) have contributed to the widespread distribution of CTV in most citrus-growing areas.

CTV has a single-stranded, positive-sense, genomic RNA (gRNA) of 19,226 to $19,296 \mathrm{nt}(18,21,31)$, with 12 open reading frames (ORFs) potentially encoding at least 17 protein products, encapsidated in flexuous particles $\approx 2,000 \times 11 \mathrm{~nm}(6)$. ORFs $1 \mathrm{a}$ and $1 \mathrm{~b}$ are translated from the gRNA, whereas ORFs 2 through 11 are expressed via subgenomic RNAs (sgRNAs) that are 3 '-coterminal $(16,18)$. Plants infected with CTV contain a nested set of $3^{\prime}$-coterminal double-stranded RNAs (dsRNAs) that are replicative forms of the gRNA and sgRNAs (16). Additionally, CTV-infected plants also may have defective RNA (D-RNA) molecules containing both the $5^{\prime}$ and $3^{\prime}$ termini of the gRNA but lacking most of the central region $(3,20,22,32)$. The D-RNA molecules were encapsidated in CTV particles (22).

CTV isolates frequently differ in the intensity of symptoms induced in different citrus species $(4,27)$, but the molecular basis for this variability is unknown. Evidence for the presence of more than one genomic variant in some CTV isolates has been obtained by biological methods $(12,15,23,24)$, reaction with monoclonal antibodies $(8,17)$, dsRNA pattern $(23-25)$, and restriction fragment

Corresponding author: P. Moreno; E-mail address: pmoreno@ivia.es

Publication no. P-1999-1209-01R

(C) 2000 The American Phytopathological Society length polymorphism analysis of the coat protein gene (11). Here we report that aphid transmission of CTV isolates frequently results in variation in the populations of CTV gRNAs and D-RNAs.

\section{MATERIALS AND METHODS}

CTV isolates. A total of 14 field isolates selected in a field survey because they had different dsRNA patterns (13) were graft inoculated to sweet orange (C. sinensis $(\mathrm{L}$.) Osbeck) cv. Pineapple and then to Mexican lime ( $C$. aurantifolia (Chritm.) Swingle) seedlings for symptom observation. The same isolates also were aphid transmitted from Pineapple sweet orange to Mexican lime, using $\approx 200$ individuals of $A$. gossypii per receptor plant and the conditions described by Hermoso de Mendoza et al. (14), and graft inoculated from lime again to Pineapple sweet orange. The source isolates obtained from the field were labeled with an F plus a number (i.e., isolates T400F through T408F), whereas subisolates obtained after aphid transmission were labeled with the same number without the F (i.e., T400 through T408, respectively).

CTV isolate T-387 was obtained from an early satsuma (C. unshiu (Mack.) Marc.) illegally imported from Japan (5), and it caused severe symptoms in various citrus species, including seedling yellows (10) in grapefruit $(C . \times$ paradisi Macfad.) and stem pitting in sweet orange. After aphid transmission to Mexican lime under the same conditions (15), one of the subisolates obtained (T388) induced symptoms similar to T387, whereas another subisolate (T-390) did not induce seedling yellows or stem pitting in sweet orange. Isolates T387, T388, and T390 also were graft-inoculated to Mexican lime for symptom comparison.

Symptoms were observed in at least two successive flushes (3 to 6 months after inoculation) and evaluated in at least three Mexican lime plants per isolate. A similar number of self-inoculated plants were used as controls. Symptom intensity was rated 0 (no symptoms) to 4 (very intense symptoms). 
CTV isolates were maintained in Pineapple sweet orange seedlings grown in a temperature-controlled glasshouse $\left(18\right.$ to $\left.26^{\circ} \mathrm{C}\right)$, using an artificial potting mix (50\% sand, 50\% peat moss) and a standard fertilizing procedure (2).

dsRNA purification and analysis. The dsRNA was purified from young bark of healthy or CTV-infected Pineapple sweet orange seedlings by the method of Dodds et al. (9) under the conditions previously established (26). This procedure consisted of phenol extraction of total nucleic acids, purification of dsRNA by nonionic cellulose column chromatography, and concentration by ethanol precipitation. The dsRNA pellet was vacuum-dried and resuspended in Tris-EDTA (TE) buffer (40 mM Tris, $20 \mathrm{mM}$ sodium acetate, $1 \mathrm{mM}$ EDTA, pH 8) with $2 \mu \mathrm{l}$ of TE per $1 \mathrm{~g}$ of fresh tissue. dsRNAs were separated by polyacrylamide gel (5\% acrylamide) electrophoresis in a minigel system with TE buffer and $120 \mathrm{~V}$ (constant) for $3 \mathrm{~h}$, stained with ethidium bromide, and photographed under UV light.

When used for northern blot analysis, dsRNAs were denatured, separated in a $0.9 \%$ agarose gel containing $1.9 \%$ formaldehyde, and electroblotted onto a nylon membrane, as described by Lewandowsky and Dawson (19).

Complementary DNA probes and blot hybridizations. A total of 10 complementary DNA (cDNA) clones were selected from a randomly primed cDNA library obtained from the severe CTV isolate B2 (1) and used as probes. Their size and position in the CTV genome are indicated in Table 1 . Clones were ${ }^{32} \mathrm{P}$-labeled with $\alpha-{ }^{32} \mathrm{P}-\mathrm{dCTP}$ and the Prime-a-Gene labeling system (Promega Corp., Madison, WI) following the manufacturer's instructions. dsRNA preparations from healthy and CTV-infected plants were used as the target in dot-blot hybridization. dsRNA concentrations were estimated in polyacrylamide gel stained with ethidium bromide, and similar concentrations of the gRNA replicative form were used. The preparations $(2 \mu \mathrm{l}$, usually equivalent to $1 \mathrm{~g}$ of fresh bark tissue) were heat-denatured at $100^{\circ} \mathrm{C}$ for $2 \mathrm{~min}$ in $50 \%$ formamide, chilled on ice, and spotted on a prewetted polyvinylidene difluoride membrane (Immobilon N, Millipore Corp., Bedford, MA). After air-drying, membranes were baked for $1 \mathrm{~h}$ at $80^{\circ} \mathrm{C}$ under vacuum and kept until hybridization. Membranes were prehybridized in $6 \times \mathrm{SSC}(1 \times \mathrm{SSC}$ is $0.15 \mathrm{M}$ sodium chloride plus
$0.015 \mathrm{M}$ sodium citrate, $\mathrm{pH} 7.0$ ), $5 \times$ Denhardt's solution (30), $1 \%(\mathrm{wt} / \mathrm{vol})$ sodium dodecyl sulfate (SDS), and salmon sperm $(100 \mu \mathrm{g} / \mathrm{ml})$ single-stranded DNA (ssDNA) (Promega) for $3 \mathrm{~h}$ at $55^{\circ} \mathrm{C}$ and hybridized with the probe for $16 \mathrm{~h}$ under the same conditions. After hybridization, membranes were washed three times (15 min each) in $2 \times \mathrm{SSC}$ and $0.1 \% \mathrm{SDS}$ at room temperature, three times in $0.1 \times \mathrm{SSC}$ and $0.5 \%$ SDS at $55^{\circ} \mathrm{C}$, and twice in $2 \times$ $\mathrm{SSC}$ at room temperature. Hybridization was detected by autoradiography with X-Omat S film and Omatic-X cassette with amplifying screen (Eastman Kodak Co., Rochester, NY).

Northern blot hybridization with denatured electroblotted dsRNA was performed with two cDNA probes (provided by M. Mawassi, University of Florida, C.R.E.C., Lake Alfred) that contained the first $7005^{\prime}$-terminal nucleotides and the first $4003^{\prime}$-terminal nucleotides of the CTV gRNA, respectively. These probes were digoxigenin-labeled by polymerase chain reaction (PCR) amplification with a clone of a D-RNA from isolate T-30 as template and the DIG-DNA Labeling and Detection kit (Boehringer Mannheim, Indianapolis, IN). Hybridization was detected with a chemiluminescent substrate according to the manufacturer's instructions.

\section{RESULTS}

The intensity of symptoms caused by field isolates (T400F to 408F) and aphid-transmitted subisolates (T400 to 408) on Mexican lime was generally similar (Table 2). Conversely, the two subisolates obtained from T387 (T388 and T390) differed in symptom expression. T388 induced very intense symptoms on lime, similar to those caused by T387. T390 caused milder symptoms on lime (Table 2) and did not induce either seedling yellows in grapefruit or stem pitting on sweet orange (15).

Aphid transmission altered the dsRNA pattern of 9 of the 14 field isolates selected (Fig. 1). In addition to the replicative form of the gRNA $(\approx 19.2 \mathrm{kbp})$, a variable number of more rapidly migrating dsRNAs was observed in each isolate. Comparison of dsRNA patterns of the field and aphid-transmitted isolates (lanes with upper and lowercase letters, respectively) showed three types of differences: (i) disappearance of some dsRNAs present in the field

TABLE 1. Dot-blot hybridization pattern of several Citrus tristeza virus (CTV) isolates and their aphid-transmitted subisolates with different complementary DNA (cDNA) probes ${ }^{\mathrm{a}}$

\begin{tabular}{|c|c|c|c|c|c|c|c|c|c|c|}
\hline \multirow[b]{2}{*}{ Isolates $^{b}$} & \multicolumn{10}{|c|}{ cDNA probes (size in nucleotides) } \\
\hline & $\begin{array}{c}\text { R-58 } \\
86(1,172)^{\mathrm{c}}\end{array}$ & $\begin{array}{c}\text { R-16 } \\
84(3,396)\end{array}$ & $\begin{array}{c}\mathrm{I}-21 \\
112(6,532)\end{array}$ & $\begin{array}{c}\mathrm{I}-54 \\
285(8,229)\end{array}$ & $\begin{array}{c}\text { R-38 } \\
119(8,423)\end{array}$ & $\begin{array}{c}\text { I-63 } \\
131(8,811)\end{array}$ & $\begin{array}{c}\mathrm{R}-17 \\
67(11,053)\end{array}$ & $\begin{array}{c}\mathrm{I}-10 \\
337(12,474)\end{array}$ & $\begin{array}{c}\mathrm{R}-14 \\
158(13,811)\end{array}$ & $\begin{array}{c}\text { R-13 } \\
194(14,677)\end{array}$ \\
\hline T-387 & ND & + & \pm & ++ & + & - & + & +++ & ++ & ++ \\
\hline T-388 & + & +++ & + & - & ++ & - & +++ & ++ & +++ & ++ \\
\hline T-390 & +++ & + & +++ & +++ & ++ & +++ & ++ & +++ & +++ & +++ \\
\hline $400 \mathrm{~F}$ & ++ & + & + & - & ++ & +++ & + & +++ & +++ & + \\
\hline 400 & ++ & - & + & - & ++ & +++ & + & +++ & ++ & + \\
\hline $401 \mathrm{~F}$ & + & + & ++ & - & + & +++ & + & + & + & + \\
\hline 401 & + & + & ++ & - & - & ++ & + & - & + & + \\
\hline $402 \mathrm{~F}$ & ++ & - & + & - & + & +++ & + & +++ & + & + \\
\hline 402 & ++ & - & + & - & +++ & +++ & ++ & ++ & +++ & ++ \\
\hline $403 \mathrm{~F}$ & ++ & - & ++ & - & +++ & +++ & ++ & +++ & +++ & ++ \\
\hline 403 & + & - & + & - & ++ & ++ & + & ++ & + & ++ \\
\hline $404 \mathrm{~F}$ & +++ & ++ & +++ & - & +++ & +++ & +++ & +++ & +++ & ++ \\
\hline 404 & + & + & +++ & - & - & ++ & + & - & + & ++ \\
\hline $405 \mathrm{~F}$ & ++ & + & + & - & + & +++ & ++ & +++ & +++ & + \\
\hline 405 & - & - & - & - & + & - & - & - & - & + \\
\hline $406 \mathrm{~F}$ & +++ & + & ++ & - & +++ & +++ & +++ & +++ & +++ & ++ \\
\hline 406 & + & +++ & +++ & - & - & +++ & +++ & + & ++ & +++ \\
\hline $407 \mathrm{~F}$ & ++ & - & + & - & + & +++ & ++ & +++ & +++ & + \\
\hline 407 & + & ++ & +++ & - & - & +++ & ++ & + & ++ & +++ \\
\hline $408 \mathrm{~F}$ & + & - & + & - & + & + & + & - & + & + \\
\hline 408 & - & - & - & - & - & + & - & - & + & +++ \\
\hline
\end{tabular}

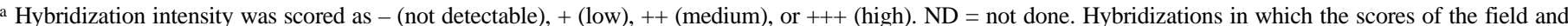
aphid-transmitted isolates differ by at least two points are boxed.

b Isolates with the same number correspond to the field (coded with F) and aphid-transmitted (without F) isolate.

${ }^{c}$ Location of the first nucleotide of the probe in the genomic RNA of CTV isolate T36 (18), numbered from the 5' terminus. 
isolate, (ii) appearance of some new dsRNAs not observed in the source isolate, or (iii) disappearance of some dsRNAs and appearance of new ones (Fig. 1). These differences were confirmed in at least two dsRNA preparations from each isolate. Isolate T387 and aphid-transmitted subisolates T388 and T390 did not show obvious differences in their dsRNA patterns (data not shown). Periodic dsRNA analysis over 2 years of infected Pineapple sweet orange plants showed that the pattern induced by each field or aphidtransmitted isolate remained unchanged.

Northern blot hybridization with the 5'- and 3'-termini probes of the CTV gRNA showed that all dsRNAs hybridized with the 3'terminal probe, but only the replicative form of the gRNA and several of the more rapidly migrating dsRNAs hybridized with the

TABLE 2. Intensity of symptoms induced by several field isolates of Citrus tristeza virus graft-inoculated or aphid transmitted to Mexican lime ${ }^{\mathrm{a}}$

\begin{tabular}{lcc}
\hline Isolate & Vein clearing & Stem pitting \\
\hline Graft-inoculated & 4 & 4 \\
T-387 & 4 & 4 \\
T-387 & 3 & 2 \\
T-400F & 2.5 & 2 \\
T-401F & 3 & 2 \\
T-402F & ND & ND \\
T-403F & 2.5 & 3 \\
T-404F & 2.5 & 3 \\
T-405F & 2 & 1 \\
T-406F & 2.5 & 2.5 \\
T-407F & 2.5 & 3.5 \\
T-408F & & \\
Aphid transmitted & & 4 \\
T-388 & 4 & 3 \\
T-390 & 3 & 3 \\
T-400 & 2.5 & 3 \\
T-401 & 2.5 & 3 \\
T-402 & 3 & 3 \\
T-403 & 3 & 3.5 \\
T-404 & 2.5 & 3 \\
T-405 & 3 & 2 \\
T-406 & 2 & 2.5 \\
T-407 & 1.5 & 3 \\
T-408 & 2 & \\
\hline Symptom & \\
\hline
\end{tabular}

a Symptom intensity was evaluated on a scale of 0 to 4 , where $0=$ no symptoms and $4=$ very intense symptoms. Values were averaged from at least three plants. $\mathrm{ND}=$ not done.
5 -terminal probe (Fig. 2). The size of these dsRNAs varied from $\approx 0.9$ to $4 \mathrm{kbp}$. Again, aphid-transmitted subisolates often differed from their source isolate by the lack of some dsRNAs or the presence of new ones. For example, after hybridization with the 5 -terminus probe, isolate T402F (Fig. 2, lane b) showed a prominent dsRNA that was not present in T402, whereas this subisolate contained two intensely reacting dsRNAs that were not detected in the field isolate (Fig. 2, lane B).

The dot blot hybridization results of $10 \mathrm{cDNA}$ probes with field isolates T387 and T400F to T408F and with aphid-transmitted subisolates T388, T390, and T400 to T408 are summarized in Table 1. Considering only the cases in which hybridization intensity differed in at least two scores (Table 1, boxes), all the field isolates could be discriminated from their aphid-transmitted subisolates, except pairs T400F/T400 and T401F/T401. Sometimes discrimination was
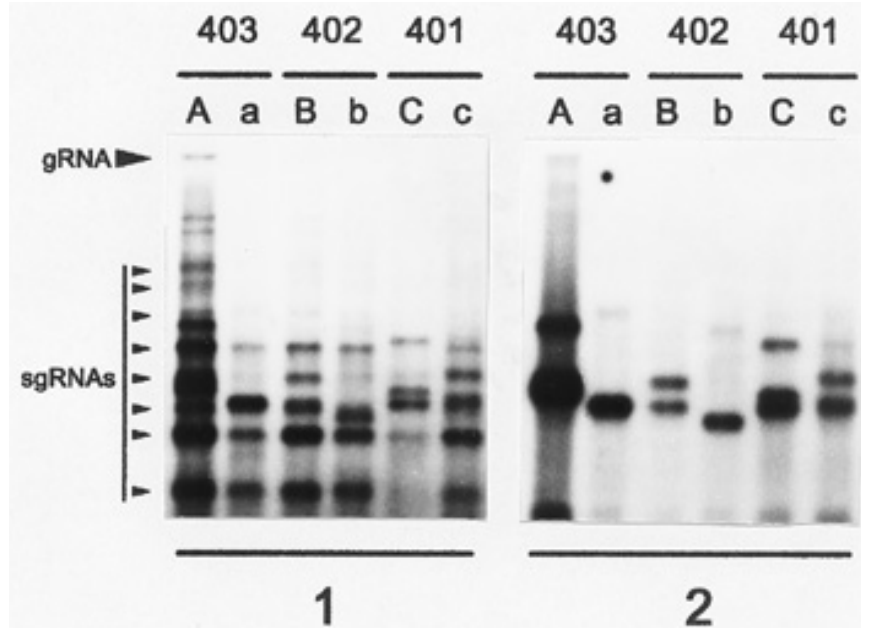

Fig. 2. Northern blot hybridization of double-stranded RNA (dsRNA) from Citrus tristeza virus field isolates T403F, T402F, and T401F (lanes a, b, and c, respectively) and corresponding aphid-transmitted subisolates T403, T402, and T401 (lanes A, B, and C, respectively) with complementary DNA probes of the $5^{\prime}$ (panel 2) and 3' (panel 1) termini of the genomic RNA (gRNA). dsRNAs were denatured, separated in a denaturing $1.9 \%$ agarose gel, electroblotted onto nylon membranes, hybridized with digoxigenin-labeled probes, and the reaction was developed with a chemiluminescent substrate. Subgenomic RNA $=$ sgRNA.

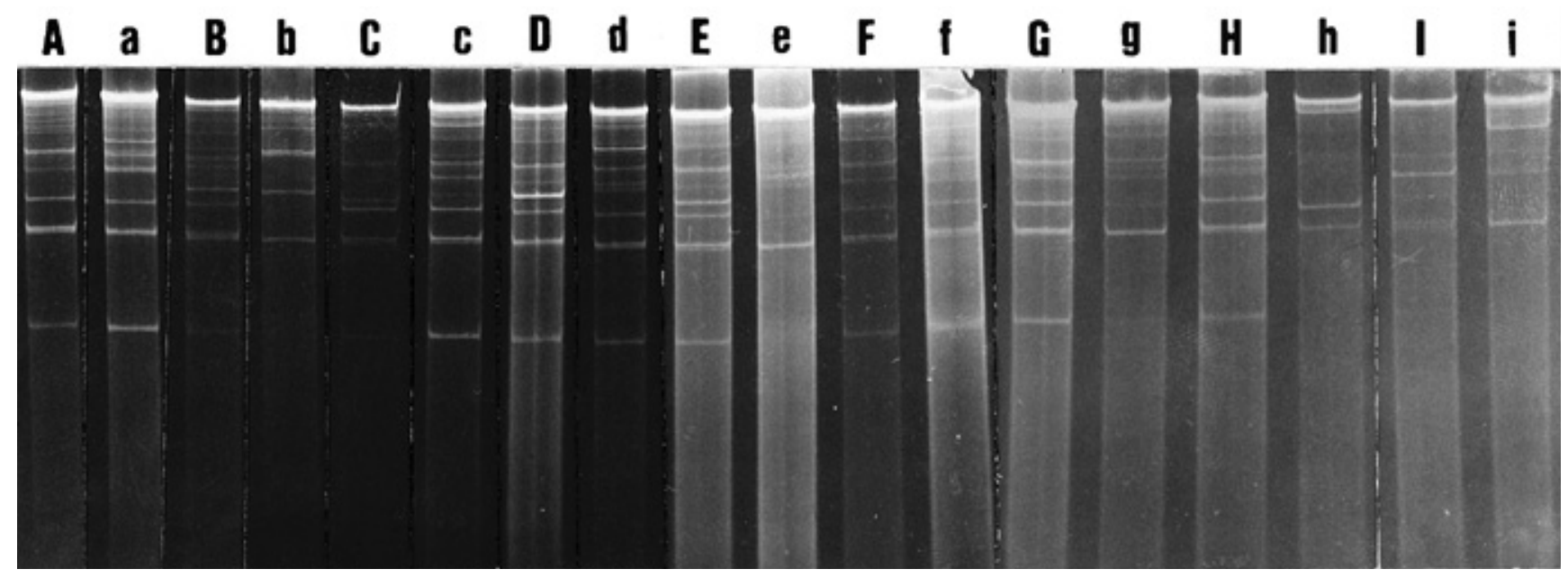

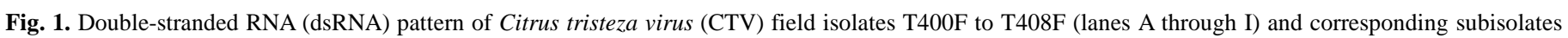

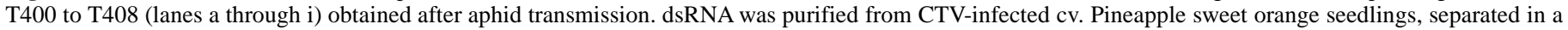

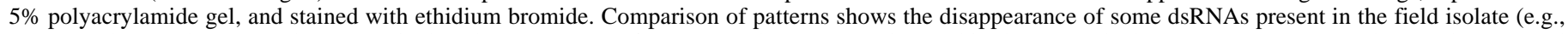

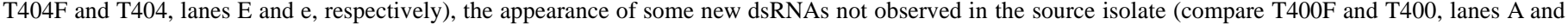

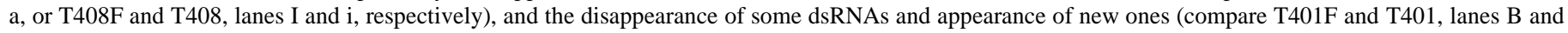

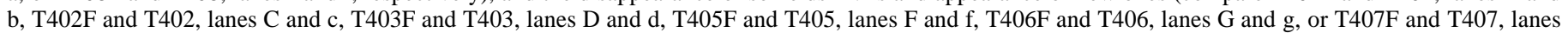
$\mathrm{H}$ and $\mathrm{h}$, respectively). 
based on hybridization with just one probe; in other cases, differential hybridization occurred with up to five probes. Use of some of the probes resulted in an intense hybridization signal with the source isolate but not with the aphid-transmitted subisolate, whereas others resulted in the opposite (Table 1 and Fig. 3).

\section{DISCUSSION}

Transmission of 14 Spanish and 1 Japanese CTV isolates by $A$. gossypii often resulted in changes in their molecular characteristics and sometimes changes in their biological properties. Of the 14 Spanish isolates, 9 showed modifications in their dsRNA pattern, consisting of the loss of some dsRNAs, the appearance of some new dsRNAs in the aphid-transmitted subisolate, or both. All of the dsRNAs observed hybridized with the 3 '-terminal probe of the CTV gRNA, but only a few hybridized with the 5'-terminal probe. This group included the replicative form of the gRNA and some faster-migrating dsRNAs that contain both termini of the gRNA but lacked most of the central region. These are replicative forms of D-RNAs, similar to those found in a variety of CTV isolates $(3,20,22,32)$. Changes observed in the electrophoretic patterns of dsRNA and in northern blot hybridizations with the 5'-terminal probe after aphid transmission indicate the disappearance of some D-RNAs, the appearance of new ones, or both.

Because D-RNAs are encapsidated (22), they can be transmitted by aphids. However, transmission of D-RNAs was not detected in most cases, even when a large number of aphids was used and transmission rates ranged from 75 to $100 \%$, indicating either that D-RNAs were not transmitted by aphids or they were unable to replicate in the new host plant. Only the smallest D-RNA in isolates T401F and T401 (Fig. 2, lanes c and C) might have been aphid transmitted, because both D-RNAs had the same electrophoretic mobility and hybridized similarly with both of the $5^{\prime}$ - and 3'-termini probes. These probes are 700 and $400 \mathrm{nt}$, respectively, indicating that both D-RNAs have high nucleotide identity in more than $50 \%$ of their length. Sequence comparison of the $5^{\prime}$ termini of D-RNAs and the gRNA from the same CTV isolate showed that both were very similar or identical $(3,22)$, indicating that DRNAs might be preferentially generated from the gRNA variants that are predominant in the population. Aphid transmission could sort some gRNA variants and give rise to a different population in aphid-inoculated plants. This shift in the predominant gRNA variants could cause the changes observed in the D-RNA populations.

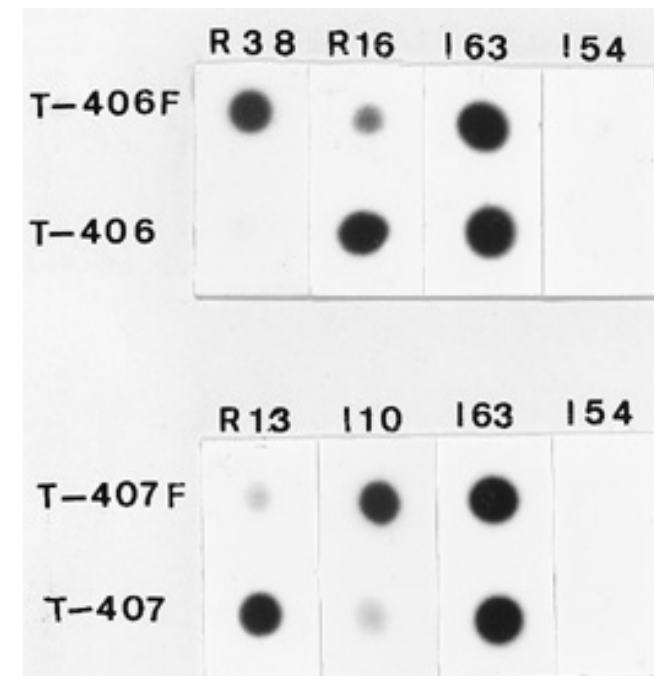

Fig. 3. Dot-blot hybridization of double-stranded RNA (dsRNA) extracts from two field isolates (T406F and T407F) and corresponding aphid-transmitted subisolates (T406 and T407) with various complementary DNA probes (sizes and locations indicated in Table 1). dsRNA was heat-denatured in 50\% formamide, spotted onto nylon membranes, hybridized with ${ }^{32} \mathrm{P}$-labeled probes, and the reaction was developed by autoradiography.
Molecular hybridization with different cDNA probes supported the idea that some of the gRNA variants present in CTV isolates are not transmitted by aphids or remain at low titer levels in newly infected plants, whereas others may increase their titer levels in the new population. The lack of hybridization of some aphid-transmitted subisolates with a probe that recognized the corresponding source isolate (Table 1) indicates that the sequence variant homologous to this probe disappeared or was at very low titer levels after transmission. Conversely, intense hybridization of certain subisolates with a probe not recognizing their source isolate (Table 1) suggests that the sequence variant homologous to this probe was at undetectable titer levels in the source isolate but became abundant after aphid transmission. D-RNAs usually accumulate at high titer levels in CTV infected tissues; therefore, variations in the hybridization pattern after aphid transmission could be attributed to changes in the D-RNA population. However, two findings suggest that this was not the case: (i) isolates T387, T388, and T390 showed similar dsRNA patterns but different hybridization patterns, and (ii) the size of the D-RNAs detected ranged from 0.9 to $4 \mathrm{kbp}$, which impairs hybridization with probes located more than 4,000 nt from either terminus of the gRNA. Only probes R-58 and R-16 corresponded to sequences located within the first 4,000 nt from the $5^{\prime}$ terminus (Table 1), whereas changes in the hybridization pattern were observed with all the probes. These findings indicate that aphid transmission resulted in an altered population of gRNA variants.

The sequences responsible for the pathogenicity of CTV isolates are unknown. Conceivably, symptom expression must be determined by the composition of the population of gRNA variants and, therefore, shifting to a new predominant sequence could potentially change symptom intensity. Broadbent et al. (7) reported separation of subisolates with different pathogenic characteristics after transmission of Australian CTV isolates by Toxoptera citricida. Symptom intensity was positively correlated with the number of inclusion bodies induced in Mexican lime, but molecular characterization of these isolates was not reported. Kano and Koizumi (17) detected separation of serotypes after aphid transmission, but biological characteristics of the source and aphid-transmitted isolates were similar. In our study, only isolate T390, obtained by aphid transmission of T387, induced milder symptoms than the source isolate. The dsRNA patterns of the two isolates were indistinguishable. Conversely, the nine isolates with altered D-RNA patterns after aphid transmission showed only minor symptom differences compared with their source isolates. D-RNAs modulating symptom expression of other viruses have been reported $(28,29)$ and might also occur in some CTV isolates. However, our results do not allow conclusions about the putative effect of CTV D-RNAs on symptom expression to be drawn, because variations in the gRNA populations also were detected in most isolates.

Moreno et al. $(23,24)$ showed that some mild isolates might contain severe CTV variants able to induce intense symptoms when separated from the source isolate. In this work, we observed that aphid transmission frequently alters the populations of gRNAs and D-RNAs. These findings might explain, in part, the appearance of virulent CTV isolates in citrus areas where milder isolates were common before (27). This variability of CTV isolates is a permanent threat to the citrus industry, even in areas such as the Mediterranean, where common isolates are mild or symptomless in the citrus cultivars currently grown.

\section{ACKNOWLEDGMENTS}

This work was partially supported by grants from the Conselleria de Cultura, Educación y Ciencia (GV-3116/95) and INIA (projects SC93111 and SC-97098). M. R. Albiach-Martí was the recipient of fellowships from INIA and the Ministerio de Educación y Ciencia. We thank M. E. Martínez, M. Boil, and E. Estela for excellent technical assistance and W. O. Dawson for allowing us to use his laboratory for northern blot experiments. 


\section{LITERATURE CITED}

1. Albiach, M. R., Rubio, L., Guerri, J., Moreno, P., Laigret, F., and Bové, J. M. 1995. Diferenciación de razas del virus de la tristeza de los cítricos (CTV) mediante hibridación molecular. Invest. Agric. Prod. Prot. Veg. 10:263-274.

2. Arregui, J. M., Ballester, J. F., Pina, J. A., and Navarro, L. 1982. Influencia del sustrato y de la fertilización en el crecimiento de plantas de lima Mejicana (Citrus aurantifolia (Christm.) Swing) cultivadas en invernadero. Ann. INIA Ser. Agric. 19:61-82.

3. Ayllón, M. A., López, C., Navas-Castillo, J., Mawassi, M., Dawson, W. O., Guerri, J., Flores, R., and Moreno, P. 1999. New defective RNAs from citrus tristeza virus: Evidence for a replicase-driven template switching mechanism in their generation. J. Gen. Virol. 80:817-821.

4. Ballester-Olmos, J. F., Pina, J. A., Carbonell, E. A., Moreno, P., Hermoso de Mendoza, A., Cambra, M., and Navarro, L. 1993. Biological diversity of citrus tristeza virus (CTV) isolates in Spain. Plant Pathol. 42:219-229.

5. Ballester-Olmos, J. F., Pina, J. A., and Navarro, L. 1988. Detection of a tristeza-seedling yellows strain in Spain. Pages 28-32 in: Proc. 10th Conf. Int. Organ. Citrus Virol. L. W. Timmer, S. M. Garnsey, and L. Navarro, eds. IOCV, Riverside, CA.

6. Bar-Joseph, M., Marcus, R., and Lee R. F. 1989. The continuous challenge of citrus tristeza virus control. Annu. Rev. Phytopathol. 27:291-316.

7. Broadbent, P., Brlansky, R. H., and Indsto, J. 1996. Biological characterization of Australian isolates of citrus tristeza virus and separation of subisolates by single aphid transmissions. Plant Dis. 80:329-333.

8. Cambra, M., Camarasa, E., Gorris, M. T., Garnsey, S. M., Gumpf, D. J., and Tsai, M. C. 1993. Epitope diversity of citrus tristeza virus (CTV) isolates in Spain. Pages 33-38 in: Proc. 12th Conf. Int. Organ. Citrus Virol. P. Moreno, J. V. da Graça, and L. W. Timmer, eds. IOCV, Riverside, CA.

9. Dodds, J. A., Jarupat, T., Lee, J. G., and Roistacher, C. N. 1987. Effects of strain, host, time of harvest, and virus concentration on double-stranded RNA analysis of citrus tristeza virus. Phytopathology 77:442-447.

10. Fraser, L. 1952. Seedling yellows, an unreported virus disease of citrus. Agric. Gaz. New S. Wales 63:125-131.

11. Gillings, M., Broadbent, P., Indsto, J., and Lee, R. F. 1993. Characterisation of isolates and strains of citrus tristeza closterovirus using restriction analysis of the coat protein gene amplified by the polymerase chain reaction. J. Virol. Methods 44:305-317.

12. Grant, T. J., and Higgins, R. P. 1957. Occurrence of mixtures of tristeza virus strains in citrus. Phytopathology 47:272-276.

13. Guerri, J., Moreno, P., Muñoz, N., and Martínez, M. E. 1991. Variability among Spanish citrus tristeza virus isolates revealed by double-stranded RNA analysis. Plant Pathol. 40:38-44.

14. Hermoso de Mendoza, A., Ballester-Olmos, J. F., and Pina-Lorca, J. A. 1984. Transmission of citrus tristeza virus by aphids (Homoptera, Aphididae) in Spain. Pages 23-27 in: Proc. 9th Conf. Int. Organ. Citrus Virol. S. M. Garnsey, L. W. Timmer, and J. A. Dodds, eds. IOCV, Riverside, CA.

15. Hermoso de Mendoza, A., Ballester-Olmos, J. F., and Pina, J. A. 1988. Comparative aphid transmission of a common citrus tristeza virus isolate and a seedling yellows isolate recently introduced into Spain. Pages 6870 in: Proc. 10th Conf. Int. Organ. Citrus Virol. L. W. Timmer, S. M. Garnsey, and L. Navarro, eds. IOCV, Riverside, CA.

16. Hilf, M. E., Karasev, A. V., Pappu, H. R., Gumpf, D. J., Niblett, C. L., and Garnsey S. M. 1995. Characterization of citrus tristeza virus subgenomic RNAs in infected tissue. Virology 208:576-582.

17. Kano, T., and Koizumi, M. 1991. Separation of citrus tristeza virus (CTV) serotypes through aphid transmission. Pages 82-85 in: Proc. 11th Conf.
Int. Organ. Citrus Virol. R. H. Brlansky, R. F. Lee, and L. W. Timmer, eds. IOCV, Riverside, CA.

18. Karasev, A. V., Boyko, V. P., Gowda, S., Nikolaeva, O. V., Hilf, M. E., Koonin, E. V., Niblett, C. L., Cline, K., Gumpf, D. J., Lee, R. F., Garnsey, S. M., Lewandowski, D. J., and Dawson, W. O. 1995. Complete sequence of the citrus tristeza virus RNA genome. Virology 208:511-520.

19. Lewandowsky, D. J., and Dawson, W. O. 1998. Deletion of internal sequences results in tobacco mosaic virus defective RNAs that accumulate to high levels without interfering with replication of the helper virus. Virology 251:427-437.

20. Mawassi, M., Karasev, A. V., Mietkiewska, E., Gafny, R., Lee, R. F., Dawson, W. O., and Bar-Joseph, M. 1995. Defective RNA molecules associated with citrus tristeza virus. Virology 208:383-387.

21. Mawassi, M., Mietkiewska, E., Gofman, R., Yang, G., and Bar-Joseph, M. 1996. Unusual sequence relationships between two isolates of citrus tristeza virus. J. Gen. Virol. 77:2359-2364.

22. Mawassi, M., Mietkiewska, E., Hilf, M. E., Ashoulin, L., Karasev, A. V., Gafny, R., Lee, R. F., Garnsey, S. M., Dawson, W. O., and Bar-Joseph, M. 1995. Multiple species of defective RNAs in plants infected with citrus tristeza virus. Virology 214:264-268.

23. Moreno, P., Guerri, J., Ballester-Olmos, J. F., Albiach, R., and Martínez, M. E. 1993. Separation and interference of strains from a citrus tristeza virus isolate evidenced by biological activity and double-stranded RNA (dsRNA) analysis. Plant Pathol. 42:35-41.

24. Moreno, P., Guerri, J., Ballester-Olmos, J. F., Fuertes-Polo, C., Albiach, R., and Martínez, M. E. 1993. Variations in pathogenicity and double-stranded RNA (dsRNA) patterns of citrus tristeza virus isolates induced by host passage. Pages 8-15 in: Proc. 12th Conf. Int. Organ. Citrus Virol. P. Moreno, J. V. da Graça, and L. W. Timmer, eds. IOCV, Riverside, CA.

25. Moreno, P., Guerri, J., Ballester-Olmos, J. F., and Martínez, M. E. 1991. Segregation of citrus tristeza virus strains evidenced by double stranded RNA (dsRNA) analysis. Pages 20-24 in: Proc. 11th Conf. Int. Organ. Citrus Virol. R. H. Brlansky, R. F. Lee, and L. W. Timmer, eds. IOCV, Riverside, CA.

26. Moreno, P., Guerri, J., and Muñoz, N. 1990. Identification of Spanish strains of citrus tristeza virus (CTV) by analysis of double-stranded RNAs (dsRNA). Phytopathology 80:477-482.

27. Roistacher, C. N., and Moreno, P. 1991. The worldwide threat from destructive isolates of citrus tristeza virus-A review. Pages 7-19 in: Proc. 11th Conf. Int. Organ. Citrus Virol. R. H. Brlansky, R. F. Lee, and L. W. Timmer, eds. IOCV, Riverside, CA.

28. Romero, J., Huang, Q., Pogany, J., and Bujarski, J. J. 1993. Characterization of defective interfering RNA components that increase symptom severity of broad bean mottle virus infections. Virology 194:576-584.

29. Roux, L., Simon, A. E., and Holland, J. J. 1991. Effects of defective interfering viruses on virus replication and pathogenesis in vitro and in vivo. Adv. Virus Res. 40:181-212.

30. Sambrook, J., Fritsch, E. F., and Maniatis, T. 1989. Molecular cloning: A Laboratory Manual. Cold Spring Harbor Laboratory, Cold Spring Harbor, NY.

31. Vives, M. C., Rubio, L., López, C., Navas-Castillo, J., Albiach-Martí, M. R., Dawson, W. O., Guerri, J., Flores, R., and Moreno, P. 1999. The complete genome sequence of the major component of a mild citrus tristeza virus isolate. J. Gen. Virol. 80:811-816.

32. Yang, G., Mawassi, M., Gofman, R., Gafny, R., and Bar-Joseph, M. 1997. Involvement of subgenomic mRNA in the generation of a variable population of defective citrus tristeza virus molecules. J. Virol. 71:98009802 . 